\title{
ARCHITECTURAL CONCEPTS FOR VALUE CHAINS
}

\author{
A.C. Janse van Rensburg ${ }^{1}$ \\ ${ }^{1}$ Department of Industrial and Systems Engineering \\ University of Pretoria, South Africa \\ antoniej@up.ac.za
}

\begin{abstract}
The Porter Value Chain has been widely adopted by the business community as a mechanism to understand and comprehend complexity in business environments, with the ultimate goal of structuring the business to maximize its competitive advantage. Implementing the Value Chain is not easy: a number of organizations can testify to their failure to derive any benefits at all from this concept. To overcome this problem, an approach is presented to assist the organization in creating a Value Chain reference model within the broader context of the organization's enterprise architecture.
\end{abstract}

\section{OPSOMMING}

Die "Porter Waardeketting" is 'n algemene aanvaarde praktyk wat deur maatskappye gebruik word om die kompleksiteit van besigheidsomgewings mee te verstaan. Die uiteindelike doel hiervan is om die besigheid se mededings voordele te optimiseer. Om die Waardekettingkonsep te implementeer, is nie 'n maklike taak nie - verskeie organisasies kan getuig van mislukte implementeringspogings. Hierdie artikel beskryf ' $n$ benadering beskryf wat gebruik kan word om die organisasie te help om 'n Waardekettingmodel te skep in die bree konteks van die organisasie se besigheidsargitektuur. 


\section{INTRODUCTION}

The concept of the Value Chain was made popular by Harvard University's Professor Michael Porter. The Porter Value Chain has been widely adopted by the business community as a mechanism to understand and comprehend complexity in business environments, with the ultimate goal of structuring the business to maximize its competitive advantage. Implementing the Value Chain is not easy: a number of organizations can testify to their failure to derive any benefits at all from this concept. From experience across more than fifty Value Chain projects in different industries, this is mainly due to the abstractions required to construct a sensible Value Chain for the organization. This problem is exacerbated when the organization tries to implement these concepts in real-world situations without first 'decoding' abstraction back to reality. Feller et al [10] support this by commenting that the concept of the Value Chain is still unclear after more than twenty years' use.

Gartner [11] classifies organizations into three categories: vertical, hybrid, or collaborative. The vertical organization owns all process steps in its supply chain, from raw material supply to the final product or service. Hybrid organizations allow third parties to produce certain product or service components in their supply chains. The third and most radical business model, collaborative, emphasises vendor management to source and produce different components of the final product or service. The collaborative organization focuses on exploiting what needs to be done, at what specification level, and how third parties fit together in this "collaborative organizational web" [23]. Although the initial work by Porter stimulated early interest in Value Chains, Feller et al [10] identify a number of significant trends that require analysis from a Value Chain perspective, and that support the move towards collaborative organizations. These trends include the increasing focus on innovation as an element of strategy, the evolving governance models for extended organizations, globalisation of supply and production, and business benefits already achieved out of manufacturing in supply chains. Van Rensburg [24] states that in order to operate this model successfully, emphasis must be placed on customer service, business process outsourcing, information technology, and organizational knowledge.

A successful Value Chain needs to form part of the overall strategy to create and maintain organizational knowledge. This paper deals with an approach to achieve this, not in isolation from the initiative, but inclusive of the overall organization and its resources, using the Enterprise Architecture (EA) methodology to provide the domain, principles, processes, and methods to create this reference model for the Value Chain. In this, the starting point for creating the Value Chain is a basic business pattern, or business fractal, with which to describe the organization [24]. By being able to answer six questions about the business fractal, the analyst can expand it into a comprehensive Value Chain. This is done effectively if a systems thinking approach is followed.

\section{SYSTEMS THINKING AND BUSINESS FRACTALS}

The history of problem-solving shows that a feasible way to solve problems is to build models of real-world situations. These real-world models, whether a simple equation or a complex dynamic simulation model, enable the problem-solver to observe and 
understand the basic concepts of the problem to be solved [1]. The use of models to understand and solve problems is similar to the way in which the human brain handles complex problems. According to Harry [9], mental models built by the human brain consist of carefully selected information: features that are not needed for our understanding are blocked by the model. Thus the use of models is important, as they present abstract views of how complex real-world situations function [14].

Scientific models are defined as abstract representations of reality, based upon scientific rules, to reduce the complexity of the problem situation. Within a model, the problem-solver tries to eliminate those real-world details that do not influence the relevant parts of the problem [4]. Therefore, a model will reveal what its creator believes is important in solving the problem. According to Curtis et al [4], this 'insight and understanding' into the problem forms the basic building blocks for a suitable model to study the system. Dijkstra [8] discovered that the idea of structuring problems through models was not futile. He found that in many natural instances, which an observer would describe as chaotic and random, patterns exist that can be described by some kind of mathematical formula.

In essence, the Value Chain approach is a problem-solving approach - that is, it tries to structure understanding of the organization in such a way that it can be used to solve the problem [8]. Unfortunately, it is not easy to study and find solutions to problems: the closer the observer looks at the real world, the more its complexity is revealed [9]. The success and efficiency of building models is measured against the ability of the modelling technique to capture descriptive and meaningful relationships in the problem environment. Using this as the criterion for evaluation, problem-solving methodologies can be distinguished either as those that produce a quality solution, or as those that are not likely to produce one because they lack good problem-solving characteristics. According to Checkland and Scholes [3], using a methodology with specific methods is not the only issue to be considered: it should also address the factors of consolidation and notation. 'Consolidation' is the means whereby the methodology consolidates the different views and perceptions of stakeholders into one common understanding and resolution of the problem. 'Notation' supports consolidation through the use of common symbols and notations to describe the problem.

One such a model for structuring the problem is the business fractal [24]. Mandelbrot and Hudson [18] define a fractal as a shape that can be broken into smaller parts, each echoing the whole. Van Rensburg [24] argues that a business fractal is a shape (or fractal) that echoes the business system as a whole and can be broken into smaller parts. In the definition of a business fractal, pictures or graphical models describe the system components through basic business geometric shapes [6]. Mandelbrot and Hudson [18] maintain that graphical models or pictures are undervalued in science due in part to the 200-year-old legacy of the French mathematicians Lagrange and Laplace, who laboured to reduce all logical thinking to formulae and carefully chosen words. In its completeness, a business fractal is a function of a shape or pattern that has memory and possesses volatility. The pattern is a simple geometric shape that forms the deterministic part of the business fractal. Memory (or autocorrelation) defines the shape, size, and timing of recurring events in the fractal, while volatility describes the power law behaviour of the fractal. Combining the shape, memory, and volatility into a business fractal, a business system (the organization) can be modelled 
in part by a deterministic pattern, and its stochastic behaviour through the memory and volatility functions. For the purposes of this paper, the deterministic pattern is the main focus area of the business fractal. By using the Enterprise Architecture philosophy, the business fractal expands the simplest form of the business pattern in the organization to that of the broader fractal, which spans all processes in the supply chain of the organization.

\section{SETTING THE ENTERPRISE ARCHITECTURE CONTEXT}

A change is required in the way the organization operates when facing the growing business trends and challenges in collaborative organizations. In turn, doing this requires an appropriate change management framework with its own set of principles, processes, tools, and techniques. Trying to achieve business excellence within this framework adds different management philosophies - such as Total Quality Management, Lean Services, Six Sigma, Theory of Constraints, Just-in-Time, or Business Process Re-Engineering - to the approach. In this multitude of philosophies, approaches, and techniques, Van Rensburg and Claasen [5] suggest the use of one modelling approach to solve many diverse industrial engineering and management problems in an integrated manner: Enterprise Architecture.

The objective of an Enterprise Architecture (EA) is to give the organization a mechanism to construct its business processes in an architectural manner - that is, balancing process, resource, people, and customers in such a way that change can be dealt with effectively and efficiently through capable and mature business processes. EA gained impetus with the USA's Clinger-Cohen Act (CCA) of 1996. This act assigned the Chief Information Officer $(\mathrm{CIO})$ the responsibility of "developing, maintaining, and facilitating the implementation of a sound and integrated information technology architecture" [21].

According to De Vries and Van Rensburg [7], in the past EA was the responsibility of an organization's information technology unit(s). However, many architecture efforts were remote from reality and represented by complex diagrams. Combining the EA purpose with organizing whole business processes delivered information technology projects as separate solutions for each strategic initiative. This - in combination with stand-alone systems and error-prone and patchy data - caused EA projects to fail more often than being successful [20]. This led to the realisation by organizations that EA is not an information technology issue, but rather a business issue. Ross et al [20] captured this by noting that EA should strive to provide the high level logic for business processes together with information technology capabilities, thus serving as a blueprint for the organization's future direction rather than trying to achieve an end state with EA. Bernard [2] states that it should be done with an holistic and integrated view of the strategic direction, business practices, information flows, and technology resources of the organization. To add to the comments from Bernard, EA provides room for applying most management philosophies to the organization without compromising the integrity of the organization's business processes. By answering the four questions - "Are the processes identified and established?", "Are the processes effective in producing the required results?", "Are the processes appropriately described in the procedure?", and "Are these procedures implemented and maintained as documented?"- the organization establishes good practices in a quality approach. 
A good Enterprise Architecture is a collection of principles, processes, and methods used to understand, design, build, implement, and maintain business processes in an holistic manner in respect of role definitions and hierarchy considerations. It abstracts reality into conceptual terms so that we can isolate and understand the interactive roles and relationships between people, processes, resources, strategy, and customers. Within the Enterprise Architecture, the Value Chain defines the way the business processes are structured in the organization to explain and manage its key capabilities. It divides the company's functions into technological and economic activities that are required to do business.

\section{THE VALUE CHAIN DEFINITION}

In the 1960s and 1970s, analysts used the concept of a Value Chain to depict the development path of mineral-exporting economies [17]. The popularity of the Value Chain as an analytical structure tool increased as the work of Michael Porter was published [17]. According to Porter and Miller [16], the 'Value Chain' concept divides an organization into the conceptually distinct activities it requires to do business. These activities create value, for which buyers are willing to pay. If the value exceeds the costs required to maintain activities, the organization is profitable. Thus, effective Value Chains generate profits [10]. Using the Value Chain in a strategic manner requires the organization either to perform these activities at lower levels than its rivals, or to differentiate itself to command higher prices [15].

Porter [15] defines a Value Chain as having nine generic activities. The five primary or core activities are Inbound Logistics, Operations, Outbound Logistics, Marketing and Sales, and Service. Support activities in the Value Chain support the primary core activities, and include Procurement, Technology Development, Human Resource Management, and Infrastructure. Using this framework, Van Rensburg [25] uses a simplified version of the Value Chain to group activities in the Value Chain into strategic, tactical, operational, and supporting activities. In this process, the importance of the statement, "Value is in the eye of the beholder", becomes evident [10]. This means that a Value Chain is created from the perspective of what the stakeholder perceives to be important to the organization.

Porter and Miller [16] suggest that the Value Chain forms part of a bigger system, the 'Value System'. This Value System incorporates upstream activities such as raw material purchasing, and downstream activities such as retailing to the final customer. Using the Supply Chain Operations Reference Model (SCOR) [26] and the Value Chain Operations Reference Model (VCOR) [27] developed by the Supply Chain Council [26] and the Value Chain Organization [27] respectively, it is proposed that the Value Chain forms the activities within the boundaries of the organization, which then in turn forms part of the supply chain, linking suppliers to customers. Supply Chain Management emerged in the 1980s as a philosophy to manage the flow of activities between suppliers of raw materials and the final customer. Olivier coined the term "supply chain management" after developing an integrated inventory management process to balance the trade-offs between his client's desired inventory and customer service goals [17].

Porter and Miller [16] define the competitive scope for the organization through four dimensions: segment scope, degree of vertical integration, geographic scope, and 
industry scope. In these dimensions, or breadth of activities, the company seeks to optimise its competitive advantage. At the two extremes, a broad scope (high volume, low variety) allows competitive advantage to be sought through commonality in components, workforce, or using interrelationships between different Value Chains serving different industry segments, etc. In contrast, a narrow scope (low volume, high variety) requires tailoring the Value Chain to specific market segments to obtain differentiation. This customization of the Value Chain tries to offer the best service to particular products or customers or geographic regions.

Using the Value Chain to impact the organization usually requires attention to the interfaces between Value Chain activities. Optimization or coordination, or simply alignment between the activities, requires the identification of those, as well as exploiting relationships between them. In the business fractal approach, the Value Chain activity needs to deal with three types of eventson the physical side of the organization: material, information, and customers. These three events are either used as input into the Value Chain, or transformed into output throughout the Value Chain.

\section{DESIGN PRINCIPLES FOR THE VALUE CHAIN}

A number of principles need to be followed in the design of the Value Chain to create the appropriate architectural governance for the model [12]. These principles deal with conceptual models, best practices, improvement, and quality considerations. The main consideration and opportunity, however, is to design it to incorporate management best practices and philosophies as the organization evolves its corporate thinking and operational execution.

The Value Chain is a conceptual model of the organization. This model needs to guide the analyst in the structuring of business complexity to enable understanding and alignment between the organization's value-added activities. It must take into account best practices as depicted by models such as the Value Chain Operations Reference model [27], Supply Chain Operations Reference Model [26] and the Zachman Framework [22].

Formal improvement processes such as project management and change management guide the implementation of the Value Chain model in the organization. This implementation should preferably be followed with a philosophy such as Lean-Six Sigma - that is, using Six Sigma to establish and manage the continuous improvement of processes in the Value Chain via identified key performance indicators, and Lean as a process optimization method. Using a Total Quality Management (TQM) approach as an overall management philosophy, the Value Chain is based on the premise that the organization is managed in a systemic and consistent manner. The eight core quality principles to achieve this are based on those promulgated by the Internal Standards Organization, covering the following:

a) Customer-focused organization - organizations depend on their customers and therefore should understand current and future customer needs, meet customer requirements, and strive to exceed customer expectations. 
b) Leadership - leaders establish unity of purpose, direction, and the internal environment of the organization. They create the environment in which people can become fully involved in achieving the organization's objectives.

c) Involvement of people - people at all levels are the essence of an organization, and their full involvement enables their abilities to be used for the organization's benefit.

d) Process approach - a desired result is achieved more efficiently when related resources and activities are managed as a process.

e) Systems approach to management - identifying, understanding, and managing a system of interrelated processes for a given objective contributes to the effectiveness and efficiency of the organization.

f) Continual improvement - a permanent objective of the organization.

g) Factual approach to decision making - effective decisions are based on the logical and intuitive analysis of data and information.

h) Mutually beneficial supplier relationships - such relationships between the organization and its suppliers enhance the ability of both organizations to create value.

\section{SIX QUESTIONS FOR THE VALUE CHAIN MODEL}

Sowa and Zachman [22] created the Zachman framework as a systemic taxonomy of concepts to relate real-world things to abstract models in the information systems discipline. The framework helps the analyst to view the world as a system from many perspectives, as well as how they relate to each other. Using the framework as an EA guide, the Value Chain is constructed within the broader context of the organizational objects and relationships identified by the framework. This means that the Value Chain forms one part of the possible 30 models (Zachman cells) in the EA framework (see Figure 1).

From an Enterprise Architecture perspective, two views are important to analyse and design business processes within the organization. The first is the functional view of the business; the second is the process view of the organization. Understanding these views, allows the business analyst to follow a simple and effective transition from the functional view to the process view and back, if required. In the Zachman framework, both views are used to describe the Enterprise Architecture of the organization.

The Zachman framework consists of two dimensions (see Figure 1): the abstraction filter and the role filter. The first dimension, the abstraction filter, provides different abstractions across the business. This means that complexity can be maintained by describing, for example, the data abstraction, whilst suppressing other information such as function or network. The second dimension, the role filter, provides a horizontal view of the business from different perspectives. For every role level, the role filter will represent all types of abstraction on that particular level, as well as a different set of constraints that may exist on that level. Every abstraction and role filter creates a particular Zachman 'cell' in the framework. Each of these views may be either a functional or a process view. In most instances in the Zachman framework, a particular cell is created and supported from a functional view, but in the 'Supply Chain Process' cell, for example, most descriptions will be those of a process view. 
The development of the Value Chain within this context requires six analytical questions to be answered: what?, how?, where?, who?, when?, and why?. Together these six questions identify the abstractions of data (what?), function (how?), network (where?), people (who?), time (when?), and motivation (why?). From a role perspective, these six questions will provide different answers for the different role levels being analysed.

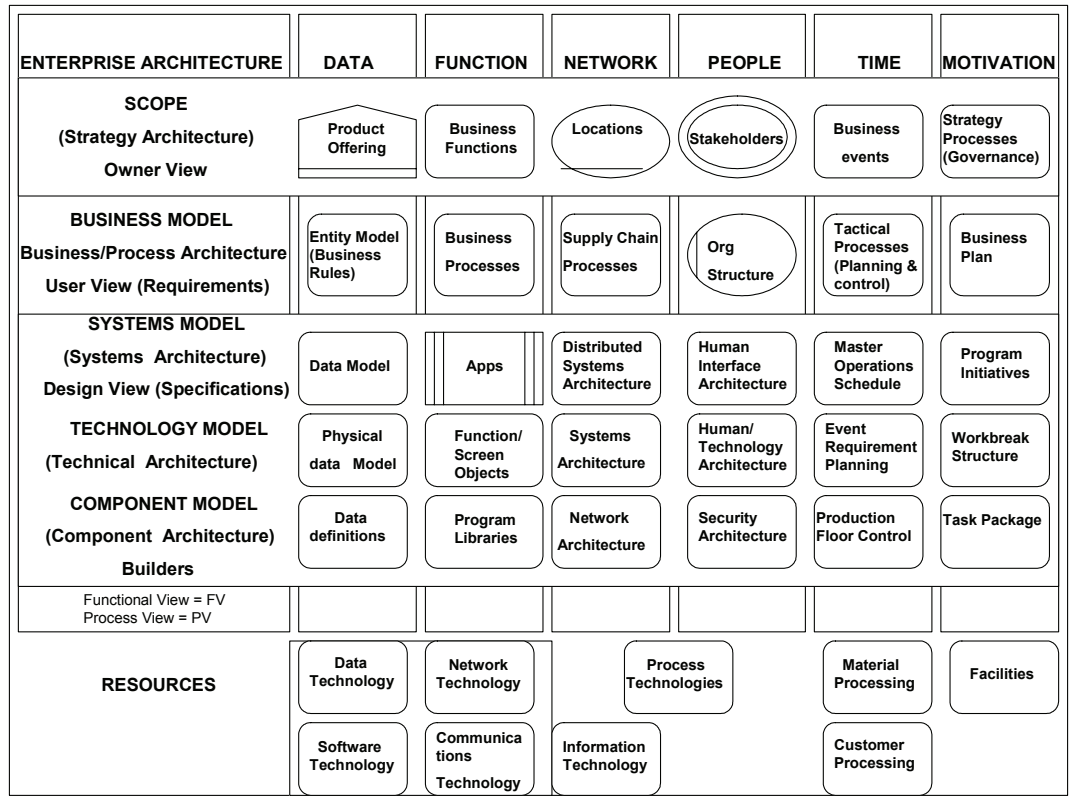

Figure 1: Adapted from the Zachman framework

\section{CREATING THE VALUE CHAIN}

Creating a Value Chain for the organization requires a combination of the functional and process views of the organization. The best way to create the Value Chain is to use the 'Business Process Ladder' procedure (Figure 2) to identify important business processes, and hence the Value Chain from those processes. In this procedure the functional view of the AS-IS (from top to bottom) forms the right hand side of the ladder, the process view; the bottom, and the TO-BE view, from bottom to top on the left side (see Figure 2). To complete the right side of the ladder, moving from top to bottom, the analyst uses the organization's structure to discover which jobs are being done, what tasks/activities are performed in these jobs, and the required skills to perform the job. After this, the analyst and the management team need to define how value is delivered through the Value Chain to the organization's customers, using focus areas such as product, customer segmentation, and functional or delivery channels. 
Upon agreement on how the Value Chain is going to be structured to deliver product and services to customers, the tasks identified on the AS-IS side are strung together to depict the end-to-end flow of processes. Using the newly structured Value Chain as the process foundation, the process is reversed on the left side (the TO-BE). Here the tasks are grouped together to support the identified processes, what skills they require, which jobs are required for the identified skills, and - as a final step - the creation of the new organizational structure. Supporting these steps, the analyst needs to understand how things are currently structured in the organization, what they should look like in future, and how the transition is going to be achieved. The EA model as depicted by the Zachman framework provides a number of cell views to assist in this process:

a) Organization Chart, which can be found in the People Column and Business Model Row.

b) Strategic Objectives and Key Performance Indicators in the Motivation Column and Scope Row.

c) List of products and services from the Data Column and Scope Row.

d) Functional Breakdown from the Function Column and Scope Row.

e) Stakeholder list, more specifically the Customer View from the People Column and the Scope Row.

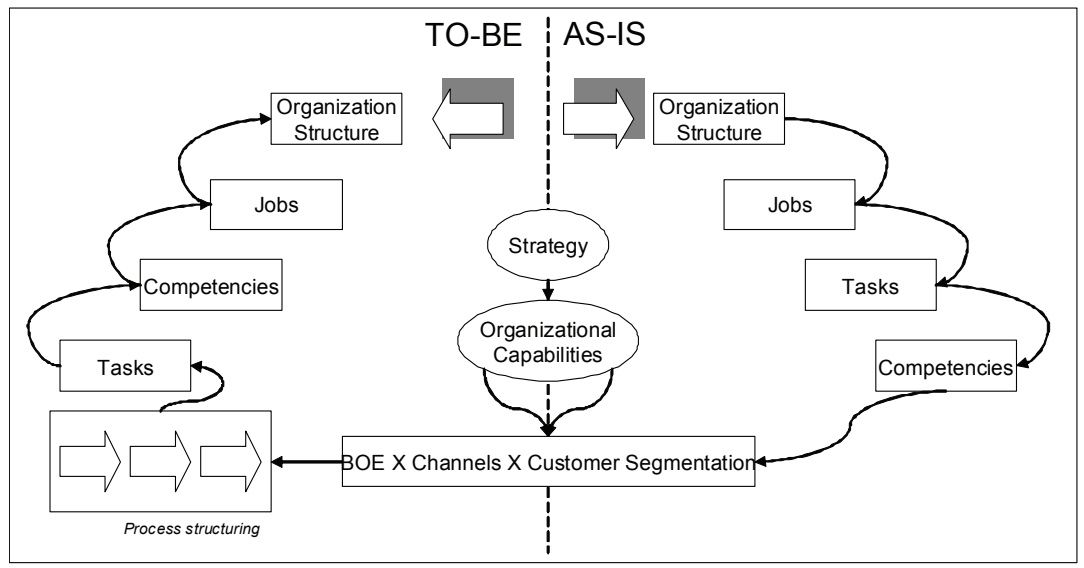

Figure 2: Business process ladder

This information provides all the required objects and relationships to build the Value Chain, except for the information required to create the different configurations of the Value Chain. As described by Porter [15], the configuration of a Value Chain is done according to four factors: a) customer segmentation, b) delivery channels, c) product and services, and d) preferential organizational structures. In practice, the organizational strategy determines how the organizational structuring will be done. This structuring can be according to the personal preference of the Chief Executive Officer, or it can be based on theoretical decisions such as the product, customer, or functions. In essence the structure will need to facilitate the most effective delivery 
of product and service to customers. The logic and reasoning for this differs from organization to organization, but will be done according to some kind of organizational logic - which ultimate creates the Value Chain reference model for the organization.

The combination of the four factors determines the Value Chain, as well as its sub-Value Chains or core processes. We can explain this by giving an example of a Value Chain exercise that was conducted for a wholesale business unit in the telecommunications industry. The business unit's organizational structure is focused on different types of trade customers, creating within the business unit seven sub-Value Chains, each focusing on a particular trade customer group. At the start of the project in the business unit, the overall Value Chain was unclear and unknown. In this project a bottom-up approach was used to discover business processes, and soon after this exercise started, seven sub-Value Chains appeared from the analysis work. Using the four factors for Value Chain configuration, the analyst was able to combine the seven sub-Value Chains into one generic Value Chain for the business unit. Applying various analysis methods and tools such as 'Single Point of Contact (SPOC)', workload analysis, and Activity Based Costing ( $A B C)$, the analyst and the management team were able effectively to understand and use the Value Chain to determine the 'competitive advantage' of the business unit.

\section{BUILDING BLOCKS FOR THE VALUE CHAIN REFERENCE MODEL}

Visual modelling is a standard practice that is used to explain Value Chains. Various modelling methods and notations exist for this purpose, but in essence the analyst can use five types of models (notations) to create a reference model for the Value Chain. Although each explains different aspects of the Value Chain, they must consolidate the views of all stakeholders in the Value Chain process.

The first model is the Context Diagram, mapping all the organization's major relationships that need to be modelled. Figure 3 shows an example of this diagram. The second model is the Functional Tree, showing the structure of lower level functions in relation to their parent functions. This model uses the Context Diagram to guide understanding of the scope of activities that the Value Chain will cover. Having constructed the Context Diagram and Function Tree, the Value Chain can be created. As a rule of thumb, the Value Chain is typically identified from the second level activities of the Function Tree. These activities create the Value Chain model, as can be seen in Figure 3.

Of interest to the analyst and the management team is the business story - that is, the story of how the Value Chain works in the organization. In order to do this, the analyst will use the fourth model; the event process chain (ePC) model. This model explains the flow, logic, decisions, and events triggering main functions in the Value Chain. In essence, it creates the story of the organization throughout the organization understanding what is being done, what is required to do it, and what relationships exist between these main functions in the Value Chain. The Relationship Map is the final model in describing the Value Chain. It is created from the information stored in the event process chains; and in this model, the flow of inputs and outputs is shown between the various Value Chain activities. This depicts the 'relational network' between the activities in the Value Chain. 


\begin{tabular}{|c|c|c|c|c|c|c|}
\hline From/To & $\begin{array}{l}\text { Marketing } \\
\text { \& Sales }\end{array}$ & Procurement & $\begin{array}{l}\text { Inbound } \\
\text { Logistics }\end{array}$ & Operations & $\begin{array}{l}\text { Outbound } \\
\text { Logistics }\end{array}$ & Service \\
\hline $\begin{array}{l}\text { Marketing } \\
\text { \& Sales }\end{array}$ & & $\begin{array}{c}\text { Forecast } \\
\text { Requirements/ } \\
\text { Customer Orders }\end{array}$ & & & & \\
\hline $\begin{array}{c}\text { Procureme } \\
\text { nt }\end{array}$ & & & $\begin{array}{c}\text { Raw } \\
\text { Material }\end{array}$ & & & \\
\hline $\begin{array}{l}\text { Inbound } \\
\text { Logistics }\end{array}$ & & & & $\begin{array}{l}\text { Material } \\
\text { Release }\end{array}$ & & \\
\hline Operations & & & & & Final Product & \\
\hline $\begin{array}{l}\text { Outbound } \\
\text { Logistics }\end{array}$ & & & & & & $\begin{array}{c}\text { Customer } \\
\text { Order/ } \\
\text { Service } \\
\text { Request }\end{array}$ \\
\hline Service & & & & & & \\
\hline
\end{tabular}

Table 2: Relationship Map

A visual notation of the Value Chain is not enough, but it is the starting point for Value Chain discussions. Real value is added to the Value Chain if these models are used to assist and support Value Chain optimisation approaches.

\section{VALUE CHAIN OPTIMISATION}

Implementation and use of the Value Chain reference model is not done in cookbook recipe fashion: it requires that multi-dimensional aspects of the business across time and change initiatives be addressed. A good practice to follow for this is the typical Edward Deming Cycle: Plan, Do, Act and Control. Combining this with the classical principles of operational and organizational design, the Value Chain reference model can be used to engage the appropriate process capabilities in appropriate ways. This means that the model is used to discover the existing performance (AS-IS) of a business process in the Plan step of Deming's cycle. Next, the model is used to discover the existing baseline of process performance through the link with the organization's key performance measurements. This leads to analysis of process performance to discover root causes for non-conformance or under-performance. Variance in performance can be resolved by developing proposed change initiatives (TO-BE), which should be investigated to address any gaps that may exist in the current process performance (Do). After approving the particular change initiative, the design of the new process, the implementation (Act), and the evaluation of the implemented design (Control) are completed. This process will only be effective if the Value Chain is used as part of proper project management, performance management, and change management practices [23].

Value Chain understanding enables Value Chain optimisation. At this level of abstraction, three approaches to optimisation can be followed. The first deals with the strategic analysis of activities towards achieving strategy; the second addresses evaluation against best practices; and the third analysis revolves around the business processes supporting the Value Chain.

In the first approach, Value Chain activities are mapped back to the strategic maps of the organization. A technique such as the Balanced Scorecard helps to establish the relationships between key objectives, key performance indicators, and the business 
processes supporting these key performance indicators. In the same approach, the Relationship Map is used to analyse relationships between the Value Chain activities.

The second approach towards Value Chain optimization is to analyse the Value Chain according to a number of best practices to be found in the Operations Management discipline. These practices include the following:

a) The nature of supply and demand is used to understand the characteristics of the customer market that the Value Chain serves. Typical parameters used include 'High Volume/Low Volume', 'High Variety/Low Variety', and 'Customer Contact Levels'.

b) Process maturity levels indicate the levels of capability maturity in the organization's business processes [25].

c) Best Practice Value Chain activities (VCOR and SCOR) provide detailed best practice function definitions, measurements, and interfaces for Value Chain activities.

d) Performance objectives cover the standard objectives of speed, quality, flexibility, cost, and dependability. The nature of the supply and demand will impact on what these measurements should be.

e) Planning and control deals with how capacity and event flow (material, customer, and information) are dealt with in the Value Chain.

f) Product/process design depends on the nature of supply and demand in the business. Volume and variety positioning impact on what process focus is followed.

g) Business configuration for the supply chain, product development, and customer relations. Depending on the volume/variety positioning, the organization follows a particular make-to-stock, assemble-to-order and make-to-order approach. This impacts on how the supply chain is structured from a buy, make, and sell perspective between suppliers and customers. In product development, the organization decides on various strategies to do product development through the stages of marketing, research, and development. Customer relations on its own depends on the branding, selling, and support of new products or existing products, as well as whether new markets or existing markets are being served.

The third approach to Value Chain optimization covers the analysis of business processes within the Value Chain, using tools and techniques such as these:

a) Process change need assessment is an instrument used to determine what types of process need to be changed - for example, innovation, communication, team building, etc. This is based on a structured questionnaire to be completed by the Value Chain stakeholders.

b) Organizational readiness can measure, from a change management perspective, the willingness to support and execute changes in the Value Chain.

c) Broad or narrow competitive scope analysis can be employed to support process re-use in the Value Chain.

d) Classifying core, support, and management processes to determine gaps in existing process flows can enable correct positioning of processes in the Value Chain. 
e) Allocation of process owners, users, and customers to processes can clarify roles and responsibilities in the Value Chain.

f) Process attribute analysis can be used to understand, for example, how critical processes contribute towards meeting customer needs, ensuring business survival, or building key competitive capabilities.

g) Simple problem prioritisation forms an overall priority list for problem resolution within the identified business processes.

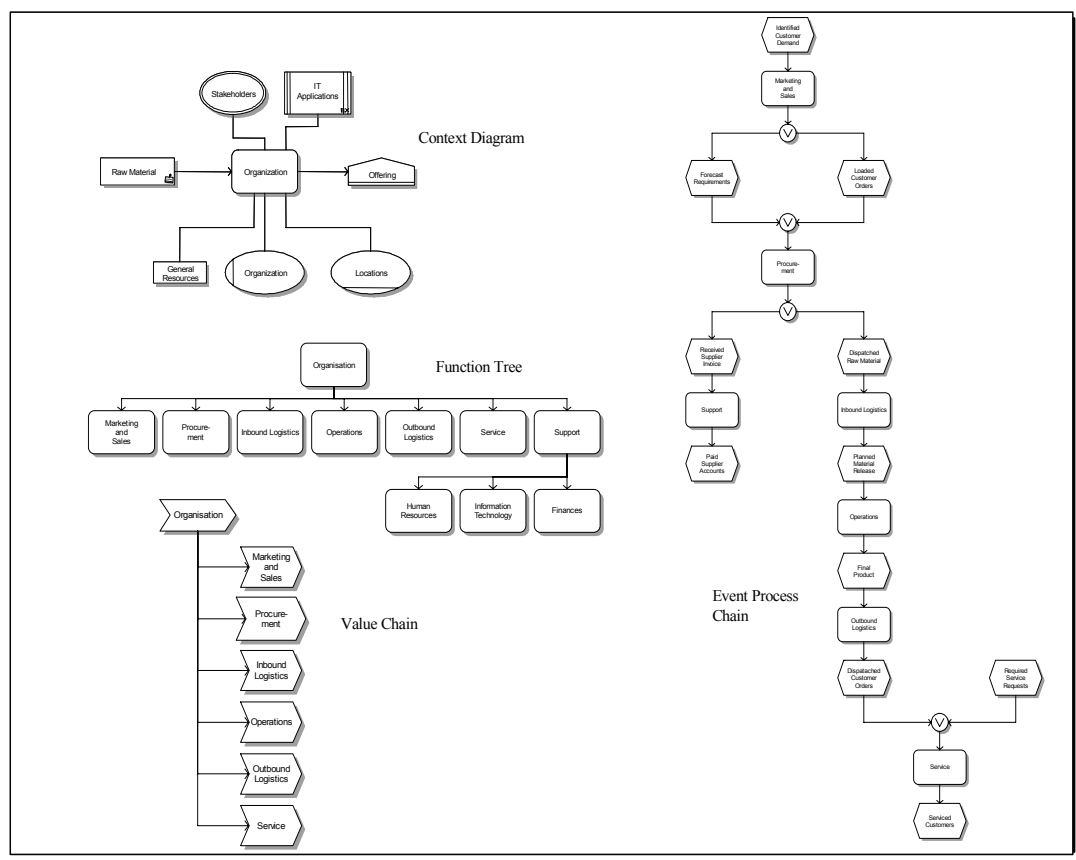

Figure 3: Value Chain reference models

\section{CONCLUSION}

Towards the end of the last century, major hype over technology drove global business. The thinking on these converging technologies and information highways was that they would create vast new open deregulated markets that were wired together and dominated by transformed organizations that were rewriting the rules of business [11]. In reality, the past six years have seen the crash of dotcom internet companies, a major recession in the United States of America stock market, and the horror of the ' $9 / 11$ ' act of terrorism. On the technology front, the world experienced the incredible growth of technologies such as Voice-Over-Internet Protocol, wireless communication, broadband, and collaborative open source software initiatives. In short, the hype that was created before the year 2000 has been replaced by solid business models that 
have real impact on the way people do business today. These incredible changes, which have taken place in a few short years, show organizations that the pace of change is here to stay - and even more, that they will have a profound and continuing impact on business, as the technology innovation cycle shortens day by day.

In the traditional organizational paradigm, management aims to align business strategy with business processes, resources, people, and information technology. As technology becomes a major change driver in the business, and as traditional boundaries disappear, business processes and technology are fusing together [23]. This results in digital business strategies that direct streams of work across traditional organizational, industrial, and international boundaries to form virtual or collaborative networked organizations [23]. Within this context, Feller et al [10] state that Value Chains and supply chains need to be seen as one integrated entity, where material flow and product delivery need to be synchronized and kept lean in order for information, knowledge, and financial flows to be fully integrated and instantaneous. This requires that the Value Chain enables product design to be fully integrated into the processes of operations, delivery, and customer demand.

To achieve this, the organization needs to be able to analyse and design a Value Model Operations reference model based on certain abstractions of the real world. Designing is not enough - this model needs to be pragmatic, such that it can be practically deployed in the organization, to its benefit. In this paper, a practical but holistic and integrated approach to the creation of the Value Chain has been demonstrated. This includes the process followed, as well as the typical Enterprise Architecture models used in this process to form a Value Chain that presents the major activities and capabilities of the organization.

\section{REFERENCES}

[1] Bailin, S.C. (1989). An Object-Oriented Requirement of Specification Method. Communications of the ACM, 32(5), 608-623.

[2] Bernard, S.A. (2005). An Introduction to Enterprise Architecture EA3. Second edition, Authorhouse, Bloomington, USA.

[3] Checkland, P. and Scholes, J. (1992). Soft Systems Methodology in Action. John Wiley.

[4] Curtis, B., Kellner, M.I. and Over, J. (1992). Process Modelling. Communications of the ACM, 35(9), 75-90.

[5] Claasen, S.J., Van Rensburg, A.C.J. (1997). The Open Solution Methodology approach to problem solving. South African Journal for Industrial Engineers, $8(2), 72-89$.

[6] Crowe, N. and Laseau, P. (1984). Visual Notes for Architects and Designers. Van Nostrand Reinhold Company. 
[7] De Vries M. and Van Rensburg, A. (2007). Enterprise architecture - new business value perspectives. Unpublished paper. Department of Industrial and Systems Engineering, University of Pretoria.

[8] Dijkstra, E. (1979). Programming Considered as a Human Activity. Classics in Software Engineering. Yourdon Press: New York.

[9] Harry, M. (1990). Information and Management Systems: Concepts and Applications. Pitman Publishing.

[10] Feller, A., Shunk, D., and Callarman, T. (2006). Value Chains Versus Supply Chains. BP trends, March edition.

[11] GartnerGroup. (1999). New Challenges for the IT Executive. Conference Presentation.

[12] Rosnner, B. (2006). Creating a Business Architecture: Where does it lead you? Gartner Report, November issue.

[13] Laseter, T. and Oliver K. (2003). When will supply chain management grow up? Strategy + Business, 32:20-25.

[14] Patching, D. (1990). Practical Soft System Analysis. Pitman Publishing.

[15] Porter, M. (1980). Competitive Strategy. Free Press, New York.

[16] Porter, M. and Miller, V.E. (1985). How information gives you competitive advantage. Harvard Business Review, Jul-Aug: 149-160.

[17] Kaplinsky, R. (2004). Spreading the Gains from Globalization. Problems of Economic Transition, 47(2): 74-115.

[18] Mandelbrot, B.B. and Hudson, R.L. (2004). The Misbehaviour of Markets. Basic Books, New York.

[19] Quality Management Systems. (1999). ISO /TC176/SC1 N190. International Standards Organization.

[20] Ross, J.W., Weill, P., and Robertson, D.C. (2006). Enterprise Architecture as Strategy. Creating a Foundation for Business Execution. Harvard Business School Press, Boston, Massachusetts.

[21] Schekkerman, J. (2004). How to survive in the jungle of Enterprise Architecture Frameworks. Second edition, Trafford Publishing, Canada.

[22] Sowa, J.F. and Zachman, J.A. (1992). Extending and formalizing the framework for information systems architecture. IBM Systems Journal, 31(2): 590-616. 
[23] Van Rensburg, A.C.J. (2006). Key capability areas for change in collaborative initiatives. South African Journal of Industrial Engineering, 17(2): 71-85.

[24] Van Rensburg, A. (2006). Enabling Business Process Outsourcing with Business Fractals. EUROMA International Conference: Moving up the Value Chain, 1161-1170.

[25] Van Rensburg, A. (2005). An Enterprise Portfolio Approach for the Management of Operational Improvement Strategies. EUROMA Operations and Global Competitiveness, 1(1): 1431-1440.

[26] www.supply-chain.org

[27] www.value-chain.org 